\title{
Identifikasi Parasit Intestinal Penyebab Infeksi Oportunistik dengan Studi Pengetahuan, Sikap, dan Perilaku Mengenai Hygiene pada Penderita $\mathrm{HIV/}$ AIDS
}

\author{
Insi Farisa Desy Arya, ${ }^{1}$ Ajeng Pratiwi. ${ }^{2}$
}

${ }^{1}$ Departemen Ilmu Kesehatan Masyarakat dan Kedokteran Keluarga, Fakultas Kedokteran Universitas Padjadjaran

${ }^{2}$ Departemen Parasitologi, Fakultas Kedokteran, Universitas Padjadjaran

\begin{abstract}
Abstrak
Jumlah temuan kasus HIV/ AIDS Jawa Barat semakin meningkat.Salah satu infeksi oportunistik yang menyebabkan morbiditas dan mortalitas adalah diare yang disebabkan oleh parasit intestinal. Transmisi parasit intestinal secara fekal oral mempermudah penularan dari satu orang ke orang lain. Penelitian ini merupakan penelitian deskriptif dengan cross sectional design yang bertujuan untuk memperoleh gambaran pola infeksi parasit intestinal dengan gejala diare dan jumlah CD4, serta mengukur tingkat pengetahuan, sikap, dan perilaku pasien HIV/ AIDS terhadap hygiene dan pencegahan infeksi parasit intestinal. Pengambilan sampel dilakukan dengan consecutive sampling pada bulan Oktober-November 2012, berupa pengambilan data dengan menggunakan instrumen kuisioner dan pemeriksaan sampel feses secara makroskopis dan mikroskopis dengan metode wet mount,modifiedZN, dan biakan Harada-Mori. Hasil pemeriksaan ditemukan 7 (22.58\%) parasit intestinal yaitu Cryptosporidium sp (3; 42.85\%) dan Entamoeba colli $(4 ; 57.15 \%)$ pada berbagai level jumlah CD4.Hasil analisis data kuisioner menunjukkan tingkat pengetahuan yang cukup baik $(87.1 \%)$, namun sikap dan perilaku yang masih kurang baik $(64.52 \%$ dan $58.06 \%)$.Penelitian ini merekomendasikan untuk dilakukan penelitian yang lebih besar dengan teknik pemeriksaan feses secara serologis maupun molekular untuk meningkatkan presisi dan mengurangi subjektivitas pemeriksaan, serta mengusulkan peningkatan upaya promosi kesehatan kepada pihak-pihak terkait.
\end{abstract}

Kata Kunci: HIV/AIDS, parasit intestinal, pengetahuan, praktik, sikap

\section{Identification of Opportunistic Infection by Intestinal Parasite with Analysis of HIV/AIDS Patients' Knowledge, Attitude, and Practice on Hygiene}

\begin{abstract}
The number of HIV/AIDS in West Java is increasing. One of the opportunistic infection that causes morbidity and mortality is intestinal parasite diarrhea. Fecal oral transmission method of intestinal parasite accelerate the spread of the disease. The investigation performed in this project is a descriptive project through cross sectional design which is intended to acquire the pattern of the intestinal parasite infection with diarrhea symptom and CD4 amount along with analyzing the knowledge, attitude, and practice of HIV/AIDS patients on hygiene and the prevention of intestinal parasite infection. Samples are collected through consecutive sampling from October 2012 to November 2012 which was perform through the use of questionnaire and feces sample analysis (macroscopic and microscopic) through wet mount, modified ZN, and Harada-Mori culture. The result shows that 7 (22.58\%) intestinal parasite which are Cryptosporidium sp (3; 42.84\%) and Entamoeba colli (4; 57.12\%) on different level of CD4. The questionnaire shows a satisfactory level of knowledge (87.1\%) and low level of behavior $(64.52 \%$ and $58.06 \%)$. From the result of the experiment, it is recommended to perform further investigation through molecular serological feces analysis to increase the accuracy of the experiment and minimize the subjectivity of the investigation. The results also shows the necessity to increase the awareness of hygiene behavior from every related party.
\end{abstract}

Keywords: Attitude, HIV/AIDS, intestinal parasite, knowledge, practice.

\footnotetext{
Korespondensi :

Insi Farisa Desy Arya, dr., M.Si,

Departemen Ilmu Kesehatan Masyarakat Fakultas Kedokteran Unpad

Jl. Eijkman No. 38 Bandung

e-mail: ifda77@gmail.com
} 


\section{Pendahuluan}

Jumlah kasus infeksi Human Immunodeficiency Virus (HIV) di Indonesia dilaporkan semakin meningkat. Sampai dengan tahun 2006, Kementerian Kesehatan Republik Indonesia memperkirakan terdapat 169-216 ribu orang terinfeksi HIV di Indonesia. ${ }^{1}$ Di Jawa Barat berdasarkan laporan triwulan Dinas Kesehatan Provinsi Jawa Barat, jumlah kasus HIV/AIDS meningkat rata-rata 300 orang setiap triwulan. Dan sampai bulan Juni tahun 2010, dilaporkan jumlah kumulatifkasus HIV/AIDS sebanyak 5.536 kasus. ${ }^{2}$

Peningkatan kasus HIV/ AIDS diikuti dengan meningkatnya jumlah kasus infeksi oportunistik seiring dengan semakin menurunnya sistem pertahanan tubuh penderita. Salah satu manifestasi klinis infeksi oportunistik yang masih menyebabkan tingginya angka morbiditas dan mortalitas pada penderita HIV/AIDS adalah diare. Berdasarkan laporan surveilans AIDS Depkes RI tahun 1987-Juni 2010, kasus infeksi oportunistik tertinggi adalah TBC (11.287 kasus), diikuti dengan diare (6.392 kasus) dan kandidiasis (6.412 kasus). ${ }^{2}$ Salah satu agen utama penyebab diare pada pasien HIV/ AIDS adalah parasit intestinal. ${ }^{1}$

Beberapa spesies protozoa intestinal yang telah diidentifikasi dapat menyebabkan diare diantaranya Cryptosporidium parvum, Isospora belli, Microsporidia sp, Giardia intestinalis, Entamoeba histolytica, Cyclospora sp, Blastocystis hominis, dan Dientamoeba fragilis. Nematoda seperti Strongyloides stercoralis dan Ascaris lumbricoides juga dilaporkan dapat menyebabkan diare dan pada pasien HIV/ AIDS. ${ }^{3}$

Perilaku hyiege dan sanitasi serta akses terhadap air besih dapat berpengaruh terhadap infeksi parasit oportinistik. Pada penelitia meta-analisis, hal ini menunjukkan penurunan $33 \%$ terjadinya infeksi dengan parilaku higienis dan akses terhadapa air bersih. ${ }^{4}$

Penelitian ini bertujuan untuk mengetahui gambaran parasit intestinal penyebab infeksi pencernaan pada penderita HIV/AIDS di Klinik Teratai RSHS.Karena infeksi parasit intestinal erat kaitannya dengan kebisaan dan hygiene dari penderita, maka penelitian ini juga bertujuan untuk mengidentifikasi tingkat pengetahuan, sikap, dan perilaku masyarakat dalam upaya pencegahan infeksi parasit intestinal

\section{Metode}

Penelitian ini dilakukan dengan menggunakan pendekatan cross sectional design dengan populasi adalah pasien HIV/ AIDS positif yang datang ke Klinik Teratai pada bulan Oktober-
November 2012. Teknik pengambilan sampel secara consecutive sampling dengan kriteria inklusi responden ialah pasien HIV/ AIDS positif dan bersedia menjadi responden. ytInstrumen penelitianiniberupakuisioneryang dikembangkan oleh peneliti berdasarkan literature review. Kuisioner penelitian terdiri dari 4 bagian. Bagian pertama merupakan data demografi, bagian kedua untuk mengukur pengetahuan responden tentang infeksi parasit intestinal (11 pertanyaan), bagian ketiga untuk mengukur sikap responden terhadap upaya-upaya pencegahan infeksi parasit intestinal (10 pertanyaan), dan bagian keempat untuk mengukur perilaku responden dalam mencegah infeksi parasit intestinal (10 pertanyaan). Uji coba instrumen penelitian telah dilakukan kepada 30 orang dengan hasil nilai koefisien alfa cronbach $\geq 0,63$ yang menunjukkan bahwa instrumen penelitian memiliki reliabilitas yang tinggi. Analisis data terdiri dari analisis univariat seperti mean, standard deviasi, serta frekuensi dan presentase.

\section{Hasil}

Pada periode waktu yang telah ditentukan yaitu bulan Oktober-November 2012 diperoleh 31 orang yang bersedia untuk mengikuti penelitian ini. Dari seluruh total responden, umumnya berusia $20-40$ tahun $(90.32 \%)$ dengan tingkat pendidikan terbanyak yaitu tamat SMA $(64,52 \%)$. Mayoritas responden tidak bekerja (38.71\%) dengan tingkat pendapatan keluarga perbulan umumnya kurang dari Rp. 1.050.000,00 (32.36\%). Responden yang pernah menderita diare setelah terdiagnosa HIV/AIDS sebanyak $45.16 \%$ dan jumlah responden tersebut, $22.58 \%$ memiliki riwayat diare dalam 3 bulan terakhir (Tabel 1).

Pada penelitian ini, dilakukan pemeriksaan terhadap sampel feses responden dengan teknik sediaan langsung (direct wet mount), sediaan dengan pewarnaan modifikasi Zhiel Neelsen, dan biakan Harada Mori. Melalui ketiga pemeriksaan tersebut diperoleh hasil positif parasit intestinal pada 7 (22.58\%) sampel feses responden, yang terdiri dari 4 (57.14\%) kista Entamoeba colli yang ditemukan dari sediaan langsung, dan $3(42.86 \%)$ ookista Cryptosporidium $s p$ yang ditemukan dari sediaan dengan pewarnaan modifikasi Ziehl Neelsen. Sedangkan pemeriksaan biakan Harada Mori untuk memeriksa larva Strongyloides stercoralis memberikan hasil negatif untuk semua sampel feses responden.

Infeksi parasit intestinal telah diketahui dapat menginfeksi berbagai tingkat pertahanan tubuh manusia, baik orang dengan sistem imun yang baik maupun pada keadaan imunokompromis. 
Insi Farisa Desy Arya: Identifikasi Parasit Intestinal Penyebab Infeksi Oportunistik dengan Studi Pengetahuan, Sikap, dan Perilaku Mengenai Hygiene pada Penderita HIVIAIDS

Tabel 1. Data Demografi Responden

\begin{tabular}{|c|c|c|}
\hline \multirow{2}{*}{ Data Demografi } & \multicolumn{2}{|c|}{ Total } \\
\hline & $\mathbf{n}$ & $\%$ \\
\hline \multicolumn{3}{|l|}{ Usia } \\
\hline $20-30$ thn & 13 & 41.93 \\
\hline $30-40$ thn & 15 & 48.39 \\
\hline$>40$ thn & 3 & 9.67 \\
\hline \multicolumn{3}{|l|}{ Pendidikan Terakhir } \\
\hline Tamat SMP & 5 & 16.13 \\
\hline Tamat SMA & 20 & 64.52 \\
\hline Tamat perguruan tinggi & 4 & 12.9 \\
\hline Tidak menjawab & 2 & 6.45 \\
\hline \multicolumn{3}{|l|}{ Pekerjaan } \\
\hline Tidak bekerja & 12 & 38.71 \\
\hline Pegawai & 5 & 16.13 \\
\hline Wiraswasta & 9 & 29.03 \\
\hline Petani/buruh/pelayan & 1 & 3.23 \\
\hline Lainnya & 2 & 6.45 \\
\hline Tidak menjawab & 2 & 6.45 \\
\hline \multicolumn{3}{|l|}{ Pendapatan Bulanan } \\
\hline$<1.050 .000$ & 10 & 32.36 \\
\hline $1.050 .000-2.000 .000$ & 9 & 29.03 \\
\hline $2.000 .001-6.000 .000$ & 5 & 16.13 \\
\hline Tidak menjawab & 7 & 22.58 \\
\hline \multicolumn{3}{|l|}{$\begin{array}{l}\text { Riwayat diare setelah } \\
\text { diagnosa HIV/AIDS }\end{array}$} \\
\hline $\mathrm{Ya}$ & 14 & 45.16 \\
\hline Tidak & 17 & 54.84 \\
\hline \multicolumn{3}{|l|}{$\begin{array}{l}\text { Riwayat diare } 3 \text { bulan } \\
\text { terakhir }\end{array}$} \\
\hline $\mathrm{Ya}$ & 7 & 22.58 \\
\hline Tidak & 24 & 77.42 \\
\hline
\end{tabular}

Densitas infeksi parasit intestinal juga beragam, mulai dari asimtomatik sampai dengan menimbulkan kematian.Salah satu parameter yang sering digunakan untuk monitoring sistem pertahanan tubuh adalah jumlah sel CD4 (Tabel 2).

Dari 31 responden, hanya $2(6.45 \%)$ yang datang dengan keluhan diare.Namun, tidak diketemukan infeksi parasit intestinal pada kedua sampel feses tersebut.Seluruh parasit intestinal yang ditemukan berasal dari sampel feses responden yang datang tanpa keluhan diare ataupun keluhan saluran pencernaan lainnya.

Tingkat pengetahuan responden terhadap berbagai hal yang berkaitan dengan infeksi cacing dan infeksi pencernaan lainnya. Sebagian besar responden dapat mengenali tanda-tanda infeksi saluran pencernaan yang paling umum, yaitu diare, mual, dan muntah $(93.5 \%)$, namun hanya $71 \%$ yang mengetahui bahwa gatal daerah anus pada malam hari juga merupakan tanda dari penyakit cacingan.

Tabel 2. Infeksiparasit Intestinal dengan Level CD 4

\begin{tabular}{ccccc}
\hline \multicolumn{5}{c}{ Positif } \\
CD 4 & $\begin{array}{c}\text { Crypto- } \\
\text { sporidi- } \\
\text { um sp }\end{array}$ & $\begin{array}{c}\text { E n t a - } \\
\text { m o e b a } \\
\text { coli }\end{array}$ & Negatif & $\begin{array}{c}\text { Jum- } \\
\text { lah }\end{array}$ \\
\hline$<100$ & & 1 & 6 & 7 \\
$101-200$ & & 1 & 4 & 5 \\
$201-300$ & & 2 & 6 & 8 \\
$301-400$ & 1 & & & 1 \\
$401-500$ & 1 & & 2 & 3 \\
$>500$ & 1 & & 6 & 7 \\
Jumlah & $3(9.67 \%)$ & $4(12.9 \%)$ & $24(77,43)$ & 31 \\
\hline
\end{tabular}

Pengetahuan mengenai cara-cara penyebaran parasit intestinalmenunjukkanhasil yangberagam. Umumnya responden dapat menjawab dengan benar metode penyebaran melalui makanan, namun hanya $22,6 \%$ responden yang mengetahui bahwa kotoran hewan peliharaan seperti anjing dan kucing juga dapat menjadi media penyebaran parasit-parasit intestinal pada manusia.(Tabel 3)

Dari sikap responden terhadap upaya-upaya pencegahan infeksi parasit intestinal.Dari semua item sikap dapat terlihat hampir seluruh responden memiliki sikap yang baik terhadap pencegahan infeksi parasit intestinal. (Tabel 4)

Perilaku responden tentang pencegahan infeksi parasit intestinal sangat beragam dan sudah cukup baik. Namun, terlihat upaya pencegahan dengan mengkonsumsi obat cacing secara rutin belum banyak dilakukan. Hanya $1(3.23 \%)$ orang responden yang mengaku selalu meminum obat cacing dengan rutin setiap dua kali dalam setahun, dan hanya $3(9.68 \%)$ responden yang mengaku meminum obat cacing secara rutin selama masa balita dan sekolahnya. Selain itu, kebiasaan membeli makanan terbuka di pinggir jalan juga nampaknya masih banyak dilakukan.Terlihat dari sedikitnya $(11,35.5 \%)$ responden yang tidak membeli makanan terbuka di pinggir jalan. 
Insi Farisa Desy Arya: Identifikasi Parasit Intestinal Penyebab Infeksi Oportunistik dengan Studi Pengetahuan, Sikap, dan Perilaku Mengenai Hygiene pada Penderita HIVIAIDS

Tabel 3. Pengetahuan Responden Tentang Infeksi Parasit Intestinal (n=31)

\begin{tabular}{|c|c|c|}
\hline \multirow{2}{*}{$\begin{array}{c}\text { Pengetahuan Terkait Gejala, Transmisi, dan Faktor Resiko } \\
\text { Infeksi Pencernaan }\end{array}$} & \multicolumn{2}{|c|}{ Total } \\
\hline & $\mathbf{n}$ & $\%$ \\
\hline Mencret, mual, dan muntah merupakan gejala infeksi penceraan & 29 & 93,5 \\
\hline Gatal anus pada malam hari merupakan salah satu gejala cacingan & 22 & 71 \\
\hline Cacing dapat keluar dari anus pada saat BAB & 28 & 90,3 \\
\hline Cacingan tidak dapat ditularkan melalui kotoran hewan peliharaan & 7 & 22,6 \\
\hline $\begin{array}{l}\text { Memakan sayuran mentah yang tidak dicuci bersih dapat menularkan penyakit cacingan dan infeksi } \\
\text { penularan }\end{array}$ & 28 & 90,3 \\
\hline $\begin{array}{l}\text { Cacingan dan infeksi pencernaan dapat terjadi bila memakan makanan yang terkontaminasi telur } \\
\text { cacing/parasit lain }\end{array}$ & 19 & 61,3 \\
\hline Cacing dapat masuk melalui kulit & 20 & 64,5 \\
\hline Makanan terbuka yang terkena debu/ tanah dapat menularkan penyakit cacingan/ infeksi usus & 25 & 80,6 \\
\hline Infeksi pencernaan disebabkan oleh kuman pada makanan & 28 & 90,3 \\
\hline Orang dengan AIDS lebih mudah terkena infeksi pencernaan dibanding orang tanpa AIDS & 29 & 93,5 \\
\hline Kuman penyebab infeksi pencernaan dapat diperiksa dari tinja manusia & 23 & 74,2 \\
\hline
\end{tabular}

Tabel 4. Sikap Responden terhadap Pencegahan Infeksi Parasit Intestinal

\begin{tabular}{|c|c|c|}
\hline \multirow[t]{2}{*}{ Pertanyaann } & \multicolumn{2}{|c|}{ Total } \\
\hline & $\mathbf{n}$ & $\%$ \\
\hline Masih boleh memakan sayuran mentah asal dicuci sampai bersih & 27 & 87,1 \\
\hline Sebaiknya minum obat cacing secara rutin $2 \mathrm{x} /$ tahun & 25 & 80,6 \\
\hline Bila keluar rumah harus selalu menggunakan alas kaki & 31 & 100 \\
\hline Sebelum makan harus mencuci tangan terlebih dahulu & 31 & 100 \\
\hline Menutup makanan agar tidak terkena debu dapat menghindarkan dari infeksi pencernaan & 31 & 100 \\
\hline Sebaiknya tidak membeli makanan yang dijual terbuka di pinggir jalan & 23 & 74,2 \\
\hline Air minum harus dimasak sampai mendidih terlebih dulu agar bebas kuman & 31 & 100 \\
\hline Makanan yang sudah lama diluar tidak ditutup dapat membuat saki tpencernaan & 30 & 96,8 \\
\hline Makanan harus dimasak sampai matang agar terhindar dari penyakit & 31 & 100 \\
\hline Makan obat cacing secara rutin tidak hanya untuk anak-anak tetapi juga dewasa & 28 & 90,3 \\
\hline
\end{tabular}

Dari semua item perilaku dapat diketahui bahwa tindakan yang paling sering dilakukan untuk mencegah infeksi parasit intestinal adalah dengan menggunakan alas kaki dan menutup makanan agar tidak terkena debu $(96,8 \%)$ (Tabel 5)

\section{Pembahasan}

Jawa Barat merupakan salah satu daerah endemis penyakit infeksi saluran pencernaan yang disebabkan oleh parasit. Selain karena faktor alam yang mendukung untuk pertumbuhan dan perkembangbiakan parasit-parasit tersebut, juga karena kultur atau kebiasaan masyarakat kita untuk "jajan" makanan yang dijajakan di pinggir jalan yang masih cukup tinggi. Prevalensi penyakit infeksi saluran pencernaan pada penderita HIV/ AIDS juga cukup tinggi.Namun, pada penelitian ini hanya didapatkan $22.58 \%$ sampel feses yang positifmengandung parasit intestinal. Hal ini dapat disebabkan oleh beberapa faktor, diantaranya : 1. Sampel feses yang diberikan untuk pemeriksaan mungkin bukan sampel feses segar karena keterlambatan mengirimkan sampel kembali ke Klinik Teratai. Idealnya, sampel feses harus diperiksadalamwaktu30menitsetelahdikeluarkan 2. Waktu pengambilan sampel feses tidak sesuai dengan siklus daur hidup dari parasit. Idelnya 
Tabel 5. Perilaku Responden dalam Pencegahan Infeksi Parasit Intestinal

\begin{tabular}{lcc}
\hline \multicolumn{1}{c}{ Pertanyaann } & \multicolumn{2}{c}{ Total } \\
& n & \% \\
\hline Mencuci sayuran mentah sebelum dimasak atau dimakan & 26 & 83,9 \\
Rutin minum obat cacing 2x dalam setahun & 1 & 3,23 \\
Keluar rumah menggunakan alas kaki & 30 & 96,8 \\
Mencuci tangan terlebih dulu sebelum mengkonsumsi makanan & 29 & 93,5 \\
Menutup makanan agar tidak terkena debu & 30 & 96,8 \\
Tidak membeli makanan terbuka di pinggir jalan & 11 & 35,5 \\
Memasak air sampai mendidih sebelum diminum & 27 & 87,1 \\
Tidak memakan makanan yang telah lama disimpan diluar tanpa ditutup & 16 \\
Memasak makanan hingga benar-benar matang sebelum dimakan & 51,6 \\
Minum obat cacing secara rutin pada saat usia balita dan sekolah & 29 & 93,5 \\
\hline
\end{tabular}

untuk mencari kista dan ookista, harus dilakukan pemeriksaan sampel feses yang diperoleh secara berurutan selama 3 hari, sehingga kemungkinan untuk mendapatkan hasil positif akan lebih besar. 3. Subjektivitas yang tinggi dari pemeriksa 4.Responden yang bersedia diperiksakan fesesnya merupakan responden yang sudah dalam terapi ARV, sehingga kemungkinan sistem pertahanan tubuhnya telah cukup baik, sehingga mampu terhindar dari infeksi parasit intestinal.

Namun, hal yang menarik berdasarkan hasil pemeriksaan adalah terbukti bahwa infeksi parasit intestinal dapat menginfeksi berbagai level pertahanan tubuh, sesuai dengan hasil penelitian yang dilakukan oleh Sucilatangham dkk (2010). ${ }^{5}$ Bagaimana sesungguhnya pengaruh terapi antiretroviral terhadap kejadian infeksi parasit intestinal masih harus dipelajari lebih dalam. Dari demografi terlihat bahwa jumlah penderita berdarkan gender adalah perempuan yatu sekitar $67,74 \%$. Hal ini serupa dengan penelitian di Cameroon $80,9 \%$ adalah Perempuan. ${ }^{6}$ Hal ini penting menjadi perhatian karena perempuan dalam hal penyediaan makanan sangat berperan dalam keluarga. Sehingga memberikan peranan besar baik dalam penularan maupun pencegahan penyakit di keluarga.

Hasil yang dihasilkan pada penelitian ini, seperti yang telah dikemukaan di hasil, bahwa Melalui ketiga pemeriksaan diperoleh hasil positif parasit intestinal pada $7(22.58 \%)$ sampel feses responden, yang terdiri dari $4(57.14 \%)$ kista Entamoeba colli yang ditemukan dari sediaan langsung, dan 3 (42.86\%) ookista Cryptosporidium sp yang ditemukan dari sediaan dengan pewarnaan modifikasi Ziehl Neelsen. Sedangkan pemeriksaan biakan Harada Mori untuk memeriksa larva Strongyloides stercoralis memberikan hasil negatif untuk semua sampel feses responden. Sedikit berbeda dengan penelitian yang dilakukan di Jakarta pada 318 sampel feses penderita HIV, dilaporkan $84,3 \%$ positif untuk parasit intestinal dengan Blastocystis hominis sebagai parasit yang paling sering ditemukan $(72,4 \%){ }^{7}$ Begitu pula dengan Penelitian mengenai parasit penyebab diare pernah dilakukan di Klinik Teratai pada tahun 2010 terhadap 32 penderita HIV dengan keluhan diare kronis. Namun hanya didapatkan 6 hasil positif untuk parasit intestinal $(18,75 \% ; 6 / 32)$, dengan sebaran parasit Cyclospora cayetanensis $(12,5 \% ; 4 / 32)$, Blastocystis hominis $(3,13 \% ; 1 / 32)$, dan Enterobius vermicularis $(3,13 \% ; 1 / 32) .{ }^{8}$

Secara umum, tingkat pengetahuan responden terhadap upaya-upaya pencegahan infeksi parasit intestinal sudah cukup baik, karena terdapat 27 $(87.1 \%)$ responden yang dapat menjawab dengan benar lebih dari 6 pertanyaan tentang pengetahuan. Namun bila ditinjau berdasarkan item pertanyaan, dapat terlihat bahwa pengetahuan tentang gejala infeksi cacing yang lebih spesifik dan metodemetode transmisi penyakit masih kurang baik

Umumnya sikap responden terhadap pencegahan infeksi parasit adalah baik dan positif $(64.52 \%)$.Hampir seluruh pernyataan tentang sikap dalam mencegah infeksi saluran pencernaan direspon positif oleh responden kecuali untuk tidak membeli makanan terbuka di pinggir jalan, hanya $74.2 \%$ responden yang setuju. Hal ini mungkin berkaitan dengan kultur dan tren di masyarakat kita saat ini yang cenderung untuk mencoba berbagai makanan yang unik dan hanya dapat ditemukan di pinggir-pinggir jalan hingga mungkin mengabaikan aspek kebersihannya

Perilaku pencegahan infeksi parasit intestinal secara umum masih kurang baik (58,06\%). Perilaku pencegahan dengan selalu memakai alas kaki, mencuci tangan, dan memasak makanan 
dengan baik sudah cukup baik dilakukan oleh para responden.Namun, perilaku pencegahan terkait dengan konsumsi obat cacing secara rutin saat ini maupun pada saat masa kanak-kanak dan sekolah masih sangat buruk (3.23\% dan 9.68\%). Hal ini tentu memiliki andil dalam mata rantai penularan infeksi parasit intestinal terutama infeksi cacing, sehingga permasalahan ini perlu diintervensi oleh stakeholder terkait seperti puskesmas, dinas kesehatan, maupun masyarakat itu sendiri. Seperti yang dilakukan di Awramba, South Gondar Ethopia, bahwa masalah infeksi parasit dapat dikendalikan dengan adanya kerjasama dengan organisasi sosial guna meningkatkan kesehatan lingkungan dengan meningkatkan kapasitas individu di masyarakat. ${ }^{9}$ Begitu pula dengan studi yang lain yang menyatakan untuk meningkatkan pengetahuan, sikap dan perilaku terkait penyakit parasit intestinal diperlukan pendekatan multisektor. ${ }^{10}$ Khusus bagi pasien HIV/AIDS, diperlukan secara rutin untuk melakukan pemeriksaan terkait parasit intestinal ini. ${ }^{11}$

Dari penelitian ini diperoleh gambaran bahwa infeksi parasit intestinal dapat terjadi pada berbagai tingkatan pertahanan tubuh, dan dapat menyebabkan manifestasi klinis yang beragam mulai dari tanpa gejala (asimptomatik) hingga gejala berat.Tingkat pengetahuan penderita HIV/ AIDS tentang infeksi parasit intestinal sudah cukup baik namun implementasi dalam bentuk sikap dan perilaku masih harus ditingkatkan lagi. Masih terdapatnya ketidaksepahaman mengenai pemakaian obat cacing secara rutin dan tidak mengkonsumsi makanan yang dijual terbuka di pinggir jalan harus menjadi perhatian dari pihak-pihak terkait.Karena meskipun hal tersebut tampak sederhana, namun memiliki andil yang cukup besar dalam mata rantai penyebaran infeksi.

Perlunya dilakukan studi mengenai hubungan infeksi parasit intestinal dengan efek terapi antiretroviral dan parameter-parameter sistem pertahanan tubuh dengan skala yang lebih besar dan komprehensif. Metode pemeriksaan mulai dialihkan dengan menggunakan metode lain seperti Rapid Test Diagnostic (RDT) atau molekuler untuk meminimalisir subjektivitas hasil pemeriksaan. Perlunya dilakukan upaya-upaya promosi kesehatan di masyarakat terkait dengan upaya preventif terhadap infeksi parasit intestinal

\section{Daftar Pustaka}

1. Prasetyo Heru. 2010. Intestinal Parasites Infection in AIDS Patients with Chronic Diarrhea at Dr. Soetomo General Hospital Surabaya. Indonesian Journal of Tropical and Infectious Disease.
Vol 1. No. 1 Januari-April 2010.

2. Laporan Triwulan Pengidap Infeksi HIV dan kasus AIDS s.d Juni 2010. Dinas Kesehatan Propinsi Jawa Barat.

3. Salamia N., Dwipoerwantoro P., Kurniawan A., Said M. 2010. Intestinal Parasitic Infection of Immunocompromised Children with Diarrhoea: Clinical Profile and Therapeutic Response. J Infect Dev Ctries 2010; 4(5): 309-17.

4. Eric C. Strunz, David G. Addiss, Meredith E. Stocks, Stephanie Orgen, Jürg Utzinger, Metthew C.Freeman. 2014. Water, Sanitation, Higiene, and Soil-Transmitted Helminth Infection: A Systematic Review and Meta-Analysis. PLOS Medicine. March 2014 | Volume 11 | Issue 3| e1001620

5. Sucilathangam $G$, Velvizhi G, Palaniappan N, Anna T. 2011. The Prevalence of Coccidian Parasites in and Around Tirunelveli in HIV Positive and Its Correlation with the CD4 Count. Journal of Clinical and Diagnostic Research. 2011 November (Suppl-1), Vol-5(6): 1182-1186.

6. Nkefou CN., Nana CT., Payne., Intestinal Parasitic Infection in HIV Infected anf Non-Infected Patient in Low HIV Prevalence Region, West Camroon PLOS ONE Vol. 8 Isse2; e57914: 1-6

7. Baruna Ahmad. 2011. Gambaran Jumlah CD4 Penderita HIVI AIDS Diare Kronis pada Temuan Bakteri dan Parasit Feses. Departemen Ilmu Penyakit Dalam. Bandung.

8. AIDS Epidemic Update. World Health Organization. Diakses dari http:// www.unaids.org/en/media/unaids/ contentassets/dataimport/pub/report/2009/ jc1700_epi_update_2009_en.pdf

9. Yihenew - G.,Adamu H.,Petros - B., The Impact of Cooperative Social Organization on Reducing the Prevalence of Malaria and Intestinal Parasite Infection In Awramba, a Rural Community in South Gondar, Ethiopia. Interdiciplinary Perspectives on Infectious Disease 2014; 1

10. Morrone A.,et all., Prevalence and risk factor for intestinal parasitic infection in Tigray, Ethiopia: a population based study. National Intsitute for Health, Migration anf Poverty (NHMP) 2009

11. Mahmud MA., Bezabihi AM.,Gebru RB., Risk Factor for Interstinal Parsitosis Among Antiretroviral-treated HIV/AIDS Patients in Ethopia. Int $J$ STD AIDS. 2014 Oct;25 (11):778-84 